\title{
Bio-Functionalized Nanoparticles - A Boon for Nano-drug Therapy
}

Vinita Ernest ${ }^{1}$, Joyce Nirmala $\mathbf{M}^{2^{*}}$ and Nagarajan $\mathbf{R}^{2}$

${ }^{1}$ Department of Biotechnology, DKM College for Women (Autonomous), Vellore-1, TN, India

${ }^{2}$ Department of Chemical Engineering, Indian Institute of Technology Madras, Chennai-36, TN, India

“Corresponding author: Nirmala MJ, Department of Chemical Engineering, Indian Institute of Technology Madras, Chennai, TN, India, Tel: +91 9677174200; E-mail: joycegitz@gmail.com

Citation: Ernest V, Nirmala MJ, Nagarajan R (2017) Bio-Functionalized Nanoparticles - A Boon for Nano-Drug Therapy. J Nanomed Nanotechnol 8: e147. doi: 10.4172/2157-7439.1000e147

Received date: April 01, 2017; Accepted date: April 04, 2017; Published date: April 06, 2017

Copyright: (C) 2017 Ernest V, et al. This is an open-access article distributed under the terms of the Creative Commons Attribution License, which permits unrestricted use, distribution, and reproduction in any medium, provided the original author and source are credited.

\section{Bio-functionalized Nanoparticles}

Bio-functionalization of nanoparticles has received enormous attention due to reduced toxicity as well as stability in colloidal state which prevents the nanoparticles from aggregation [1,2]. The biomolecules being used for functionalization vary from simple to complex macromolecules [3]. Starch, a natural polymer widely used in many industries as raw material was chosen for synthesis of silver nanoparticles as well as for functionalization. The one-pot synthesis was an easy procedure for both synthesis and functionalization [4]. The aldehyde group of starch serves as the functional group which attaches to the synthesized nanoparticles, thereby preventing aggregation. This stabilizes the nanoparticles, and no aggregation was visible for more than three months. A study was done to check the function and structure of starch using hydrolysis. The results were quite interesting in that the structure had no major deformities while still maintaining functionality [5].

Since the substrate starch is being fixed onto the surface of silver nanoparticles (AgNPs), the enzyme-substrate complex reaction was proceeding faster than expected. The blue-black colour disappeared $1.5 \mathrm{X}$ faster in the presence of AgNPs. The AgNPs were also functionalized with other enzymes to assess structural and functional properties. Lysozyme and amylase from different sources were functionalized over the AgNP, and the corresponding substrates were added and assessed. An increase in the enzymatic activity of enzymes was reported, and lysozyme along with AgNPs was found to have higher bactericidal properties than the free/unbound enzyme [6].

In all these studies recorded using various spectroscopic techniques, the structure of enzymes showed few modifications, whereas the function (enzyme activity) was unchanged while being pronounced in the presence of AgNPs [7]. Thus, bio-functionalization not only prevents aggregation but also helps in the immobilization of nanoparticles thereby improving the overall enzyme efficiency [8].

In summary, the immobilization of enzymes over the surface of AgNP has yielded a nano-bio-conjugate with synergistic antibacterial and catalytic properties. This strategy opens the door for the development of potential nano-drug delivery systems wherein the biofunctionalized nanoparticles are an immediate option availed in administration of drugs.

\section{Acknowledgement}

The authors thank DST-SERB, Government of India for all sources of support and funding.

\section{References}

1. Alarcon EI, Bueno-Alejo CJ, Noel CW, Stamplecoskie KG, Pacioni NL, et al. (2013) Human serum albumin as protecting agent of silver nanoparticles: Role of the protein conformation and amine groups in the nanoparticle stabilization. Journal of Nanoparticle Research 15: 1-14.

2. Iseult L (2008) Protein-nanoparticle interactions. Nano Today 3: 40-47.

3. Gebauer JS, Malissek M, Simon S, Knauer SK, Maskos M, et al. (2012) Impact of the nanoparticle-protein corona on colloidal stability and protein structure. Langmuir 28: 9673-9679.

4. Vigneshwaran N, Nachane RP, Balasubramanya RH, Varadarajan PV (2006) A novel one-pot 'green' synthesis of stable silver nanoparticles using soluble starch. Carbohydrate Research 341: 2012-2018.

5. Ernest V, Nirmala J, Sekar G, Mukherjee A, Chandrasekaran N (2013) Biophysical investigation of $\alpha$-Amylase conjugated silver nanoparticles proves structural changes besides increasing its enzyme activity. Journal of Bionanoscience 7: 1-5.

6. Ernest V, Sekar G, Amitava M, Chandrasekaran N (2013) Enhanced activity of lysozyme-AgNP conjugate with synergic antibacterial effect without damaging the catalytic site of lysozyme. In Artificial Cells, Nanomedicine, and Biotechnology pp: 1-8.

7. Ernest V, Shiny PJ, Mukherjee A, Chandrasekaran N (2012) Silver nanoparticles: A potential nanocatalyst for the rapid degradation of starch hydrolysis by a-amylase. Carbohydrate Research 352: 60-64.

8. Chen R, Choudhary P, Schurr RN, Bhattacharya P, Brown JM, et al. (2012) Interaction of lipid vesicle with silver nanoparticle-serum albumin protein corona. Applied Physics Letters 100: 013703-013701-013704. 